\title{
16. In search of momentum for national urban policy
}

\author{
Karsten Zimmermann and Valeria Fedeli
}

\section{INTRODUCTION}

The contributions in this volume display a discrepancy between the aspirations visible in European and global discourses on the necessity for strong urban policies and the actions actually undertaken by national and sub-national governments. We are not just referring to the European Urban Agenda, the New Urban Agenda of the United Nations, the renewed Leipzig Charter for sustainable urban development or OECD sources (OECD 2017) but also to the many transnational networks and agencies such as Metropolis or $\mathrm{C} 40$, which are trying to give voice to the expectations of cities all over the world for policies that are able to tackle the emerging urban challenges. Just from looking at the titles of the contributions in this book, we can clearly perceive how the context is still characterized by a lot of question marks or metaphorical insinuations such as 'waiting for Godot', 'limited, fragmented and powerless' or 'benign neglect' (these are taken from the titles of the chapters on Italy, Sweden and Ireland, respectively). In other cases, the authors question the effectiveness of national urban programmes, as well as the longstanding tradition that has generated them, in addressing contemporary challenges (e.g. France). At the same time there is no doubt that urban issues are, or have been, on the agenda of national governments such as Spain, Portugal, Romania, Poland and, recently, Slovakia.

National urban policies used to be a stable component of national policies in France, the Netherlands and Germany, but France and the Netherlands are experiencing a significant transformation, with the two countries going in totally different directions with regard to the instruments and goals of urban policies. Germany displays a rather stable pattern of central-local relations within the context of cooperative federalism. In many states, national platforms, agendas or networks exist, trying to bring urban problems to the national agenda. Usually these platforms are supported by the national government (such as POPSU in France ${ }^{1}$ or the Nationale Stadtenwicklungspolitik 
in Germany ${ }^{2}$ ), but we also observe initiatives stemming from academia (such as Urban@it in Italy ${ }^{3}$ ). The UK presents the case with the strongest disruptive changes: from a rich experience of area-based initiatives for urban regeneration to a kind of growing neglect of state-led urban regeneration and a more recent reinvention of post-urban policies. In Sweden, Norway and Ireland we can say that national urban policies have a more residual status - but for different reasons. However, at least the most recent national planning documents in Ireland, though not having an institutional anchor, include specific goals for the urban development of Irish cities.

\section{DO WE NEED NATIONAL URBAN POLICIES? AND WHICH KIND?}

One of the first questions that the chapters collected in this volume raise is whether or not it is worth having a coordinated national urban policy. What is its scope and role and, moreover, how can we measure its effectiveness? It's astonishing that all the contributions implicitly or explicitly evaluated the national urban policies of their respective countries against a very demanding definition of national urban policy as

- being integrated and profiled, significantly helping cities in solving urban problems;

- governments investing in cities because of their strategic role in the country.

Given that most of the authors in this volume are sceptical, the question arises: are expectations too high? Despite experiences during the last part of the twentieth century, it still remains unclear how and if national urban policies as we know them are able to address the urban question and consequently what kind of national urban policy is needed.

The picture that this book allows us to draw is one of great differences and uncertainties on this first issue. First of all there is a still visible distinction between those countries with residual national urban policies, cyclically emerging and under experimentation (Italy, Romania, Sweden, Norway); those which have had explicit national programmes over a longer period and are engaged in a constant attempt to reframe at best the model of public action (France, the UK, the Netherlands and Germany); and finally those which have experienced at least temporary rise of national urban initiatives (Portugal, Spain, Poland and, recently, Ireland and Slovakia).

Van den Berg et al. (2007, p. 404) in their book National Policy Responses to Urban Challenges in Europe, a reference for many years in the field in which our book has been conceived, made the distinction between three types 
of national urban policies and identified the following groups corresponding to these types: (1) explicit urban policies (the UK, France, the Netherlands, Belgium), (2) increasing policy attention to cities (Germany, Finland, Sweden, Denmark, Italy, Portugal) and (3) no explicit urban policies (Ireland, Spain, Greece, Austria, Luxembourg). Much has changed in the last 15 years, as Spain has experienced a rise of urban initiatives and Ireland clearly considers the urban dimension in its most recent national planning framework; Germany has been doing much more than just increasing the attention paid to cities (this was probably already true in 2007); the UK has experienced significant changes; and Italy was already moving towards the current situation where a new debate about urban policies is visible, as are a number of fragmented initiatives.

What is noticeable in any case is that those countries which have had explicit urban policies over a longer period have accumulated a lot of experience in specific fields, such as urban regeneration and housing policies. Indeed, many of the authors of the chapters in this book have growing and explicit doubts with regard to the effectiveness, integrated character and stability of such programmes, which are still focusing on the same, apparently unsolved, problems (see in particular the 'perpetual reinvention of categories and tools' in France, the ups and downs of national regeneration initiatives in the UK and the exploratory works of the Parliamentary Commission in Italy to identify the meaning of the 'periphery' as the target of urban policies). In many of the cases represented here, despite the growing numbers of international agendas and declared shared principles providing a worldwide overview on what should be the role of national urban policies for tackling urban challenges, the debate is far from settled. Again, despite the wide attention on policy transfer and policy mobility and the growing space for knowledge exchange supported by international institutions and events, when we get to the national arenas, off-the-shelf solutions are still contested from different points of view. It seems that national urban policies emerge in national containers. The lack of a clear-cut and shared understanding on whether there are enough intelligent, useful, effective solutions for cities and their problems remains an urgent and open policy issue. What is the nature of these kinds of policies? Are they specific, unique? Should they remain distinct or should they, rather, be framed inside a larger agenda? In many cases, even when they are organized and structured, as in France, their specificity and isolation risk trivializing what is in fact a complex policy issue, and as a consequence they often produce limited results. When, as in the German case, they are elevated to an upper strategic level, does this solution risk hiding the focus and destroying the efforts made? As a preliminary and open conclusion, the nature of national urban policies seems to require further reflection. 


\section{WHAT KIND OF URBAN IS AT STAKE?}

A second question that the book addresses concerns the nature of the object of national urban policies, a topic on which there is much open discussion. The turn towards a broader understanding of the urban, including also rural areas with structural problems, is visible in the UK (only very recently), France (in the last few years), Romania and Poland, and also in a way Italy (with a new recent nominal focus on the metropolitan dimension under the EU cohesion policy framework) and Slovakia (due to a high number of small jurisdictions, displaying a pattern of peri- and suburbanization processes with Bratislava being the centre of gravitation). This indicates there will be an eventual shift from urban regeneration policies for agglomerations to a broader set of territorial interventions for small towns in rural, suburban or peri-urban areas. On the one hand, it looks like we are witnessing a growing awareness of the fact that the urban question is not only one that affects large urban agglomerations. The Netherlands, France, Germany and Poland have established, or at least tried to establish, broader policy schemes for cities and towns of different sizes, while most of the other countries are reflecting on this issue. On the other hand, the focus on small and medium-sized cities or the suburban condition seems still to be based on a quite traditional interpretation of this question. Is it just a problem of size? Is it a problem of centrality and marginality? Can we clearly identify specific issues for specific and defined places? Of course, the efforts of national governments to interpret the urban in its different forms and to design policies which could work for cities of different sizes and natures can be largely appreciated in many countries. Nevertheless, a trap seems to lay behind the many different urban policies. In fact, even if different and differentiated, the manifold profiles of the urban that compose contemporary space must be seen as highly interrelated. The challenge then becomes how to design and implement policies able to work on situatedness and relationality: place-based and transcalar rather than bounded and universal.

In this respect, the policy dilemma is no longer whether national governments do or do not privilege some cities while paying less attention to others, but becomes how public agencies can find policies able to work in a selective and strategic way, producing impacts that can benefit urban societies in a differentiated way. This could address, for example, the resistance and opposition of different kinds of cities and citizens, which has become more and more visible in several of the countries examined, sometimes also being at the base of quite new social movements (see for example the French case). 


\section{WHO SHOULD TAKE CARE OF CITIES?}

A third question is related to the relationship between cities and the state. The insights of the chapters often contrast with the broad literature on the resurgence of Cities, Global Urban Politics and New Municipalism (Boudreau 2016; Russell 2019; Chesire 2006; Pinson 2019). Considering what the authors in this volume have been able to contribute when talking about the state-city relationship in each of their countries, we feel that often this relationship has not been adequately scrutinized in the literature. As mentioned in Chapter 1 of this book, there are different positions in this debate. On the one hand we find those contexts in which cities are considered as national champions and darlings of national governments:

Today, the state not only reinforces the role of major cities and city-regions in 'national survival' but also harnesses city-spaces, the agency of cities, their symbolic value and their supposedly creative social milieux in the constant production of the state as a territory of national wealth, power and belonging. (Moisio 2018, p. 1424)

On the other hand we find those interpretations of state-city relationships characterized by decentralization and austerity, enabling governance, and steering at a distance. The hollowing out of the state, austerity policies and the withdrawal of the state from essential policies such as housing have impacted on cities, providing them with apparent autonomy, but few resources for action.

Between these two positions we would situate the discourse on stateless urbanism or cities as 'saviours of global democracy' and sites for innovation. Some of the contributions based on this discourse create the impression that something like a stateless urban policy exists; that cities are not even in need of national governments as states have become dysfunctional and paralyzed by strained budgets and dysfunctional party structures. Evidence for this is somewhat anecdotal or refers to a few cities as global policy leaders (see, for a contrasting position and more balanced analysis, Bassens et al. 2019; Pinson 2019; Kübler and Lefèvre 2017).

The contributions in this volume shed some light on the relevance of these discourses and the implicit assumptions they make on state-city relationships. A biased national urban policy with a focus on national champions is visible in only a few cases, and even in these cases it forms only part of the story (Norway, the Netherlands, and to a limited degree Sweden), so it's not an overall pattern. Political and administrative decentralization has had a big impact on urban policies in France, Italy, Spain and Portugal, but this can't be seen as a clear victory for cities over the state (which becomes particularly apparent when looking at Italy). Overall, austerity measures have had a clear 
effect on urban policies in many states, and in the UK, the Netherlands, Italy, Spain and France in particular.

All the contributions to this volume argue for a stronger role for national governments, higher-profile national urban policies and continuous inter-institutional dialogues. Stateless urban policy does not seem to be a viable option and the most relevant national urban policies that are at stake are housing policies, urban regeneration policies, mobility policies and climate change policies. Hence, the nexus of national policies and urban welfare is still an issue. Although the strength and degree of coherence differs a lot, almost all the countries represented in this volume had implemented national urban policy initiatives (Sweden and Norway being the exceptions for different reasons). This raises the questions: does national urban policy always empower cities? Should this be the goal? How much discretion should be given to local authorities? Is strengthening local self-government in terms of finances and administrative capacity the most appropriate national urban policy? In Sweden, and to a lesser degree also in Germany, the design of national urban policies is influenced by the doctrine of local self-government (that is to say: local autonomy). Other national governments continue to intervene in local politics even if they follow decentralization agendas (France, Italy). In addition, in some states local governments are increasingly used as instruments for meeting national policy goals (climate change, sustainable energy provision; see Norway and Germany).

At the same time, while this book was in the making, the COVID-19 pandemic has opened new discussions on the renewed role for national policies in regulating the urban way of life, on the one hand, and on what kinds of cities we should strive for in the future, on the other. The two discussions together are going to stress, or are already stressing, some of the ongoing trends observed in most of the countries in this book.

\section{HOW? WHAT KINDS OF INSTRUMENTS CAN SUPPORT URBAN POLICIES?}

Throughout the chapters we find interesting reconstructions of many experimental approaches in the field. Policy instruments that have achieved widespread recognition are area-based initiatives (ABIs) with their various ramifications. There are different names for them but their character is that of a comprehensive, integrated, participatory and, more recently, place-based intervention. ABIs have been in use since the 1990s and 2000s in their various forms (Atkinson 2000; Lawless 2006) and have gained the support of many national governments and, of course, that of the EU (ISUD, URBAN II). There is an ongoing evolution of ABIs towards integrated urban development or what is sometimes called complex urban intervention. More interest- 
ingly, the area-based approach has been able to push for a new focus on the role of local societies in urban policies. The urban policy of the European Commission clearly supports this evolution and the influence is recognizable in Spain, Portugal, Italy and Poland (for the case of Italy, see Vinci 2019). The place-based approach (Barca 2009), proposed by the EU for the cohesion policy period 2014-2020, appears in more nuanced forms, being difficult to detect because of its experimental nature. Despite having become central in many national discourses, it still remains largely underdeveloped and underexploited in practice.

With regard to the choice of instruments, a difficult dilemma emerges. On the one hand, what is evident and astonishing is that one of the most pertinent issues in many countries still seems to be the lack of funding dedicated to cities. On the other hand, more interestingly, what is particularly striking is that state actors still seem to look at cities through the lens of instruments and discourses of state modernization (fiscal federalism, decentralization, deal-making, managerialism) but are not able to grasp cities as socio-spatial configurations of actors, milieux, territories and the relationships between them. In other words, when trying to design urban policies, states are acting without having a clear idea what the 'urban' is or should be. In his book Politics of Urbanism: Seeing Like a City, the Canadian Geographer Warren Magnusson clearly describes this inability of national governments to design interventions that grasp the complexity of urban development and acknowledge the nature of urban politics (Magnusson 2011). The argument presented in the book has also been debated widely in Germany, where the idea of non-partisan local self-government lost persuasiveness due to the fact that national parties gained ground in local elections.

In some cases we can find interesting state efforts to innovate in the field of public policies, such as in the case of the Dutch national urban policy, where it can also take the form of performance auditing, evaluation, intergovernmental peer review and cross-jurisdictional learning (see the chapter on the Netherlands by Bas Denters).

In other countries the interrelated nature of government is leading to an effort to generate new governance arrangements: city deals, agreements and contracting are becoming quite common, even if in different forms and with different results (the UK, the Netherlands, Norway, France and Italy are moving in this direction). On the one hand, we can find interesting initiatives able to fertilize the field. On the other hand, there is evidence of a mismatch between ordinary policy-making and extraordinary practices too much based on special conditions of leadership, sensitivity to the issue, and special events.

Quite a few of the chapters report on ambitions for better coordination of the sectoral policies of national governments. Some governments have dedicated agencies or inter-ministerial/inter-institutional steering groups. However, 
success is not self-evident. A new ministry for cities was set up in Portugal in 1999, but coordination problems at a national level were prevalent. In other cases, national urban agendas are isolated initiatives of single ministries and have often disappeared when these ministries were dissolved (see for example the Italian case). National ministries for urban affairs did exist in other countries but these have been amalgamated with other ministries or abolished. Better coordination is also needed when designing cross-ministerial urban policies (see the cases of Germany and Poland). Inter-ministerial coordination groups exist in Germany and in the Netherlands (but can be considered frustrated ambitions), and they also exist in Italy, where the issue of coordination has been recently addressed by a parliamentary commission. Policy sectors that call for national intervention include urban renewal, housing, climate change and, to some extent, mobility.

At the end of the day, initiatives for national urban policies always have an institutional nature that facilitates the cross-sectoral coordination of policies relevant for urban areas. Inter-institutional relations are an issue in Spain, where the autonomous regions are responsible for many urban policies and for legislation relating to local government (this is also partly the case in the differentiated regionalism of Italy and of course the cooperative federalism in Germany). The desire for coherent and stable national urban policies makes better coordination a necessity. In regionalized and federal states, the eventual need for sub-national urban policies has to be taken into account. However, this aspect has only been addressed in Spain, although in Germany it has been at least partially addressed in the city-states (Berlin, Hamburg, Bremen) and, in an earlier period, was addressed in Nordrhein-Westfalen.

\section{ARE CITIES STILL A RELEVANT POLITICAL ISSUE?}

A final issue centres around the political dimension and the cleavages ultimately being reflected in the agendas of political parties having either a stronger urban or non-urban basis of support. D'Albergo (2010) proposed in his paper a further differentiation between left-oriented and right-oriented governments. For some countries this still seems to be a crucial point, the urban question and the socio-economic challenges related to it still attracting the attention of governments inspired by socio-democratic ideologies, even if we can clearly see similarities and an urban focus also in conservative-liberal governments. Social Democrats in Spain as well as in France were promoters of urban welfare policies during the 1980s, and this was also the case in Germany in the late 1990s and during the 2000s. Political changes did play a role in the UK during recent decades (with continuities, however, which have gone beyond the political orientations). This connection between the policy 
orientation and the role of the urban in the political agenda has been much discussed in the literature. The contributions in this book still fail to explain how the changing nature of politics in current times can affect the relationship with the urban dimension. More than that, many of the countries discussed here are in fact experiencing an epochal restructuring of politics, sometimes reflected in the fading away of traditional political movements and parties. The French, the Spanish and the Italian cases, where government coalitions are supported by newly emerging anti-establishment movements, still show an interest in cities and urban policies; indeed, in some cases mayors have become crucial actors at national level, in others the new political movements have found a strong base in cities. At the same time, some of these new political actors have not based their campaign, or their success, on gaining the votes of cities (where voters and parties have demonstrated a more traditional attachment to traditional politics). In some cases, the focus of the newly emerging political forces is anti-urban. How is this structural change going to affect urban policies, locally and even more so at national level? Further research is needed in this direction (also with regard to the role of conservative parties in Poland and Romania, for example).

\section{SOME COMPARATIVE CONCLUSIONS}

Is it possible to conclude with a comparative view? This collection of essays has used the heuristic proposed by d'Albergo (2010) as a starting point, which has proven to be a useful instrument but needs further elaboration. As d'Albergo argued, the real nature of practices does not offer space for clear-cut typologies and often the same case offers elements which move between different typologies: in the case of several countries, such as Portugal for example, we can find simultaneously active and passive state policies.

In summarizing the chapters of this edited volume, the first overall conclusion is that it is still the case that not all national governments give high priority to the urban dimension of public policies or have explicit urban agendas and programmes. We can see a clearer evolution of national urban policies in Portugal, ${ }^{4}$ Spain and Poland (though with some discontinuities in the cases of Poland and Spain). Other states show disruptions (the UK) or clear institutional barriers (such as the doctrine of local self-government in the case of Sweden). Germany, France and the Netherlands show a continuous presence of urban issues on national agendas, but in France and the Netherlands changes are taking place in relation to form and content. In France, for instance, we are observing a shift from the Politique de la ville for the banlieue to a wider national policy scheme for all kinds of small and medium-sized towns and nonprivileged urban areas. In the Netherlands, there has been a clear shift towards more flexible and enabling policy schemes (such as the City Deals), 
with the design of complex interventions (integrated sustainable development) still being the template. One of the most significant changes happened in 2015, with the end of the Urban Policy Initiative.

In terms of policy issue characterization, the countries presented in this book show much variation and path-dependent developments. With the current level of understanding, it is difficult to build typologies. However, with the risk of stretching a concept too far, national urban policies resemble the four types of urban governance that Jon Pierre suggested in 1999 (Pierre 1999). He distinguished the four following types that we adapt and use in a nonexclusive way (i.e. a state can represent more than one type).

1. Corporatist: corporatist urban policies are distributional policies and concerted actions with a considerable degree of participation (of associations of cities, associations of renters or house owners, public housing firms, local leaders etc.). Hence, the policy style is inclusive and based on negotiations. Non-organized interest groups tend to be neglected. A large public sector as a specific form of urban capitalism is instrumental (housing associations and public utilities, see Lorrain 2005). Conflicts are solved by the deliberation of interest groups. We would consider Germany and Slovakia as being part of this group (Slovakia because of the inclusive process of the elaboration of the urban agenda for 2030).

2. Managerial: managerialist urban policies are influenced by the idea of a lean state, and often emerge as a reaction to a fiscal crisis. They tend to be asymmetric, flexible and efficiency-oriented and use procedural tools such as contracting and agreements with cities along with financial tools such as urban funds (such as JESSICA, promoted by the European Commission). They are characterized by a focus on professionalism, efficiency and monitoring of results and make an instrumental use of city-networks. As a result, urban policies are more sector-oriented (mobility, housing, climate change) and less integrated. Cities are partners, not beneficiaries. The Netherlands, Norway (where agreements are in use for climate and transport policies) and the UK are exemplary cases.

3. Pro-Growth: pro-growth urban policies see cities as agents. Often partnerships are used as instruments. Pro-growth policies are strongly outcome-oriented and give less emphasis to an inclusive process. We may add the characteristics of temporariness and asymmetric national interventions. This type of national urban policy has not been mentioned often in the chapters of this book, but we would consider Ireland, the UK, the Netherlands and to some extent France as demonstrating these features.

4. Welfare: urban welfare policies are re-distributional policies, inclusive and often with their origin in old industrial areas. Cities are beneficiaries (more passive than active, but this has changed a lot). In recent times we 
also find small and medium-sized cities as the targets of national policy schemes (France, Poland, Romania, Germany). Still, shrinkage, deindustrialization and disadvantaged neighbourhoods, urban poverty and migration are the main concerns. Urban welfare policies are equity-oriented, area-based and direct, and they encourage a stronger role for parties and relations between parties and local bureaucrats. Germany, France, occasionally Italy (in the 1990s and more recently) and the UK and the Netherlands in the past are exemplary cases.

While this tentative typology may have some heuristic merits, it does not include the criterion of funding available for urban policies.

Several factors may explain the evolution and change of national urban policies. Van den Berg et al. mention the degree of urbanization in a country, the presence of a number of large cities, the administrative framework and financial system and the emergence of typical large-city problems (van den Berg et al. 2007, p. 400). Still, explanatory models need to be more complex as the mentioned factors have a rather weak predictive quality. What has been mentioned as a new driver for national urban policies is, for example, the amalgamation and creation of big cities in the Netherlands. Nevertheless, urbanization and metropolitanization do not necessarily invoke national urban initiatives. This has been only partly true for Norway, Italy and Ireland. In general terms, what we can observe is a growing awareness of the multifaceted and interrelated nature of the urban problematique, but it still seems to be difficult for governments to come up with policies that are capable of dealing with such a situation.

Cities appear more and more engaged in the field, and their role is still very much needed, but it is also uncertain and unsettled. In some countries, cities are increasingly seen as agents implementing national policy goals and initiatives (the Netherlands, Germany, Norway) or even EU policies. This is often the case for climate policies and sometimes the case for innovation policies. This type of national urban policy differs from the urban regeneration schemes that were prevalent in the 1970s, 1980s and 1990s. In this period of urban decline, cities were in need of financial support and needed new approaches (Urban Welfare) (Pierre 1999, p. 386). Cities were beneficiaries of these funding schemes and in some cases more than just passive receivers or policy-takers. Climate change is not necessarily an urban crisis - at least not in the same way as, say, deindustrialization was - but a wider policy issue. Still, national governments need cities as policy implementing agencies in this field, an argument that we often find also at the EU level. But funding is often discontinuous and integrated in inflexible multi-level funding schemes.

As a final remark before closing the book, one cannot but notice what Behar discussed some years ago with reference to the French case: urban 
policies are highly commented upon, but poorly debated. With the comments often being negative, with few in-depth analyses, the logics of urban policies seem destined to completely change in a few years. In fact, this book clearly conveys the constant changes urban policies have gone through since the state of the art presented by van den Berg et al. in 2007. Torn between the urgency of providing solutions to problems that often become suddenly visible and explosive, despite being structural and omnipresent, and the wider need for reforms that are able to tackle more structurally the failures of public action, the ultimate design and purpose of national urban policies is an open question. At least in the last decades the heterogeneity of the urban question and the need to go beyond the overlapping of the social question with the urban question (as defined by Behar 1999) have become clearer in many contexts. Nevertheless, national urban policies still seem far from meeting the many expectations of citizens, policy-makers, experts and academics.

\section{NOTES}

1. POPSU: Plateforme d'observation des projets et stratégies urbaines, http://www .popsu.archi.fr.

2. https://www.nationale-stadtentwicklungspolitik.de/NSPWeb/DE/Home/home node.html.

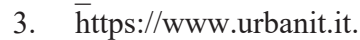

4. And that is different to the results of van den Berg et al. (2007, p. 404).

\section{REFERENCES}

Atkinson, R. (2000), 'Combating social exclusion in Europe: the new urban policy challenge', Urban Studies, 37 (5-6), 1037-1055.

Barca, F. (2009), An Agenda for a Reformed Cohesion Policy: A Place-Based Approach to Meeting European Union Challenges and Expectations. Independent report prepared at the request of the European Commissioner for regional policy, Danuta Hübner, European Commission, Brussels, Belgium.

Bassens, D., Beeckmans, L., Derudder, B. and Oosterlynck, S. (2019), 'An urban studies take on global urban political agency', in: Oosterlynck, S., Beeckmans, L., Bassens, D., Derudder, B., Segaert, B. and Braeckmans, L. (eds), The City as a Global Political Actor. London: Routledge, pp. 1-22.

Behar, D. (1999), En finir avec la politique de la ville? November, Esprit.

Boudreau, J.-A. (2016), Global Urban Politics: Informalization of the State. Malden, MA: Polity Press

Chesire, P. (2006), 'Resurgent cities, urban myths and policy hubris: what we need to know', Urban Studies, 43 (8), 1231-1246.

d'Albergo, E. (2010), 'Urban issues in nation-state agendas: a comparison in Western Europe', Urban Research and Practice, 3 (2), 138-158. DOI: $10.1080 / 17535069.2010 .481220$.

Kübler, D. and Lefèvre, C. (2017), 'Megacity governance and the state', Urban Research and Practice, 11 (4), 378-395. 
Lawless, P. (2006), 'Area-based urban interventions: rationale and outcomes: the New Deal for Communities Programme in England, Urban Studies, 43 (11), 1991-2011. DOI:10.1080/00420980600897859.

Lorrain, D. (2005), 'Urban capitalisms: European models in competition', International Journal of Urban and Regional Research, 29 (2), 231-267. DOI:10.1111/j.1468 $-2427.2005 .00583 . x$.

Magnusson, W. (2011), Politics of Urbanism: Seeing Like a City. Abingdon, UK: Routledge.

Moisio, S. (2018), 'Urbanizing the nation-state? Notes on the geopolitical growth of cities and city-regions', Urban Geography, 39 (9), 1421-1424.

OECD (2017), National Urban Policy in OECD Countries. Paris: OECD Publishing.

Pierre, J. (1999), 'Models of urban governance: the institutional dimension of urban politics', Urban Affairs Review, 34 (3), 372-396.

Pinson, G. (2019), 'Voracious cities and obstructing states', in: Oosterlynck, S., Beeckmans, L., Bassens, D., Derudder, B., Segaert, B. and Braeckmans, L. (eds), The City as a Global Political Actor. London: Routledge, pp. 60-85.

Russell, B. (2019), 'Beyond the local trap: new municipalism and the rise of the fearless cities', Antipode, 51 (3), 989-1010.

van den Berg, L., Braun, E. and van der Meer, J. (2007), 'Synthesis', in: van den Berg, L., Braun, E. and van der Meer, J. (eds), National Policy Responses to Urban Challenges in Europe. Aldershot, UK: Ashgate, pp. 399-432.

Vinci, I. (2019), 'How the EU regional policy can shape urban change in Southern Europe: learning from different planning processes in Palermo', Urban Research and Practice, online first, DOI:10.1080/17535069.2019.1672083. 